\title{
CARBOHYDRATE COMPOSITION OF RAT INTESTINE SURFACE MUCUS LAYER AFTER CEFTRIAXONE TREATMENT
}

\author{
Yu. V. HOLOTA, Ya. A. OLEFIR, T. V. DOVBYNCHUK, G. M. TOLSTANOVA
}

Educational and Scientific Centre Institute of Biology and Medicine, Taras Shevchenko National University of Kyiv, Ukraine; e-mail: gtolstanova@gmail.com

\begin{abstract}
The epidemiological studies have shown that antibiotic treatment increases the susceptibility to inflammatory bowel disease development. The disturbance of mucus layer integrity might be one of the possible mechanisms. The aim of the present study was to investigate the effect of antibiotic ceftriaxone treatment on glycoproteins level and its carbohydrate composition in surface mucus layer of rat intestine. The study was done on male Wistar rats (140-160 g). Ceftriaxone (300 mg/kg, i.m.) was administered once a day for 14 days. The surface mucus from terminal ileum and colon were collected on the $15^{\text {th }}$, $29^{\text {th }}$ and $72^{\text {nd }}$ days of the experiment. Total level of mucus glycoproteins, hexoses, hexosamines, fucose and sialic acids were measured. Ceftriaxone administration did not affect the levels of glycoproteins in rat ileum. In the colon, the levels of glycoprotein were 1.3-fold decreased $(P<0.05)$ on the $72^{\text {nd }}$ day of the experiment. These changes were accompanied by the 1.2-fold decrease of hexoses $(P<0.05)$ and 3.1-fold $(P<0.05)$ decrease of fucose level and $1.5-$ fold $(P<0.05)$ increase of the levels of sialic acids in the surface mucus of the rat colon. Thus, ceftriaxone administration induces the long-term changes in the levels of glycoproteins and carbohydrates composition in the rat colon surface mucus. This could potentially explain the susceptibility to inflammatory bowel diseases development.
\end{abstract}

K e y w ord s: antibiotics, glycoproteins, hexose, fucose, hexosamines, sialic acids.

$\mathrm{E}$ pidemiologic investigations have shown that the use of antibiotics, which occupy a leading place in the current medical practice, increases considerably the development of the inflammatory bowel diseases (IBD) and infection susceptibility [1-3]. The disturbance of function of the mucus barrier as a result of antibiotic-caused stable continuous changes of the bowel microbiota is one of potential mechanisms of such relation [3]. Thus Jernberg et al. [4] have shown that the peroral taking of klindamycine (7 days) by healthy volunteers in clinically recommended doses leads to stable disturbances of microbial association during next 2 years. A sharp decrease of diversity and continuous persistence of resistant Bacteroides strains were revealed, in particular. Similarly administration of cephoperasone, antibiotic of cephalosporine family, caused essential changes in the composition of mice cecum microbiota, which were observed even 6 weeks after the drug administration, was stopped [5].
Mucus forms two layers at the surface of colon mucosa: the internal layer devoid of microbiota and the external one colonized with microorganisms [6].

Glycoproteins (mucins) are the basic highmolecular component of mucus. About 20 different genes of mucins, from MUC1 to MUC20, in accordance with the order of their finding have been identified to date. All mucins are divided into two groups: secretory (gel-forming) mucins, such as MUC2, MUC5AC, MUC5B, MUC19, and membrane-bound (MUC1, MUC3A, MUC3B, MUC4 and others), which are localized on the apical membrane of enterocytes. MUC2 is the main secretory mucin of the small intestine and colon [7]. The protein core of mucin molecules is characterized by the variable number of tandem repeats (VNTR) that contain the great number of amino acid residues of serine and threonine with attached oligosaccharides. O-glycosylation occurs in the Golgi apparatus with adding $\mathrm{N}$-acetylgalactosamine (GalNAc) 
to hydroxyl groups of serine and threonine, forming GalNAca1-O-S/T (Tn antigen). This glycan is further elongated in positions $\mathrm{C} 3$ or C6 of GalNAc forming new core structures. The adding of sialic acid in C6 position of GalNAc is a typical feature of molecules of O-glycanes of human MUC2. As a result C6 branch is terminated. Oligosaccharide is subsequently elongated in C3 position by residues of $\mathrm{N}$-acetylglucosamine (GlcNAc) and galactose (Gal) [8]. Glycoproteins of the rat bowel contain 4 types of core structures: type I - Gal $\beta 1-3$ GalNAc $\alpha 1$; type II - Gal $11-3$ (GlcNAcb1-6)GalNAc $\alpha 1$; type III GlcNAc $\beta 1-3-G a 1 N A c \alpha 1$; and type IV - GlcNAc $\beta 1$ 3(GlcNAc $\beta 1-6)$ GalNAc $\alpha 1$ [9].

Glycanes compose $60-80 \%$ of the mass of mucin molecules. They cover protein skeleton and thus protect mucin from degradation by proteolytic enzymes and take effect on their gel-forming properties. Terminal oligosaccharides are potential ligands for microbe adhesines and nutritive substrates for symbiotic bacteria of the outer mucus layer [7].

The importance of correct glycosylation of mucins was shown on mice models with deficiency of glycosyltransferases. Thus, mice lacking $\beta 1,3-$ acetylglucosaminyltransferase (C3GnT), which adds GlcNAc residue to Tn antigen (GalNAca1-S/T) with formation of the core structure of type III, become more susceptible to development of the colon inflammation, in particular on the model of dextransulphate sodium (DSS)-induced colitis [10]. Colitis develops spontaneously in the distal sections of the colon in mice knocked out by $\beta 1,3$-galactosyltransferase (C1GalT1, or T-synthase) [11].

Residues of fucose, sialic acids and sulphated monosaccharides are localized in the terminal position of mucin oligosaccharides. Sulphation and sialylation of mucin oligosaccharides provide additional mucus stability under the destruction by bacterial glycosides $[12,13]$. Thus, not only the mucus amount, but also its quality are of the decisive importance for ensuring the barrier function.

Normal degradation of the mucus glycans is a relatively slow process, but if they become short, the decay of oligosaccharides considerably increases, and both the inner and outer mucus layer is degraded and bacteria can get through it to the epithelium surface [14].

There was the only research when administration of clinically recommended doses of antibiotics (bacitracin, clidamycin, vancomycin) conditioned the long-term changes of the general composition of fecal mucins of healthy volunteers. These changes were determined by electrophoretic distribution that was similar to that in excrements of germ-free rats [15]. But the data concerning antibiotics influence on the quantitative and qualitative composition of carbohydrate part of glycoproteins of the bowel surface mucus are insufficient.

The broad spectrum antibiotics [16] are often used today. Their action mechanism is connected with inhibiting peptidoglycan synthesis in the bacterium cell wall. Thus, this work objective was to determine carbohydrate composition and general content of glycoproteins of the rat bowel surface layer in different periods after ceftriaxone administration.

\section{Materials and Methods}

Investigations were conducted on Wistar male rats $(140-160 \mathrm{~g}, n=24) \mathrm{kept}$ in the vivarium at ESC Institute of Biology and Medicine of Taras Shevchenko National University of Kyiv under standard conditions as to temperature, illumination, humidity and diet. The experiment was carried out meeting the requirements of Bioethical Commission of the Taras Shevchenko National University of Kyiv (protocol \# 8 of November 2, 2015). The first day of administration of the acting or control substance was considered as the experiment beginning.

Ceftriaxone (Ind. Stock Company Darnytsya, Ukraine) was administered intramuscularly to animals for 14 days in a dose of $300 \mathrm{mg} / \mathrm{kg}$. The control group animals received $0.1 \mathrm{ml}$ of water for injections, respectively. The rats were killed on the 15, 29 and $72^{\text {nd }}$ days from the experiment beginning by $\mathrm{CO}_{2}$ inhalation with further cervical dislocation. A section of colon from the anus to cecum and $15 \mathrm{~cm}$ of the small intestine from the ileocecal valve were isolated during autopsy. The small intestine was cut longitudinally, washed in cool physiological solution and blotted with the filter paper. The surface mucus was separated from the layer of epithelial cells with $6 \mathrm{~N} \mathrm{~N}$-acetyl-1-cystein (Sandoz, Switherland). One centimeter of the colon from the anus and $1 \mathrm{~cm}$ of small intestine from the ileocecal valve were placed into $3 \mathrm{ml}$ of $6 \mathrm{~N} \mathrm{~N}$-acetyl-1-cystein solution to qualitatively determine the oligosaccharide part of mucus by means of Schiff reaction. The rest of the colon and small intestine was cut and plunged into testtubes with $9 \mathrm{ml}$ of $6 \mathrm{~N} \mathrm{~N}$-acetyl-1-cystein solution for further determining the content of glycopoteins, hexoses, fucoses, hexosamines and sialic acids. Each test-tube was mixed on the vortex during $4 \mathrm{~min}$, 
then the samples were centrifuged at $3000 \mathrm{~g}$ during 15 min. Supernatant was taken with sediment and supernatant liquid of $1 \mathrm{ml}$ volume remained. The content of test-tubes was resuspended and homogenized by a disperser T10 basic Ultra Turrax ${ }^{\circledR}$ (IKA, Germany) with the speed of 5 (20500 rpm) during $20 \mathrm{~s}$.

Glycoproteins were determined with the help of Schiff reaction on PVDF-membrane [17]. The PVDF-membrane (Hybond-P, Amersham International, Little Chalfont, Great Britain) was first plunged for 2 min into 100\% methanol solution, and then for 2 min into the $80 \%$ solution. Then the membrane was washed in distilled water, dried by filter paper and placed on the wet filter paper. The PVDF membrane was covered with $10 \mu$ l of homogenized sample and kept for 10-15 min to its complete absorption. The membrane was washed in distilled water during $2 \mathrm{~min}$, after that it was incubated for 10 min in $\mathrm{KOH}$ solution in $70 \%$ ethanol and then washed again in distilled water. Then the membrane was plunged into $0.5 \%$ solution of periodic acid for $10 \mathrm{~min}$, washed with distilled water and subjected to the effect of Schiff reagent during $30 \mathrm{~min}$ at permanent shaking. After that the membrane was twice incubated in $0.6 \%$ sodium metabisulphate during $3 \mathrm{~min}$ and washed in distilled water during $3 \mathrm{~min}$ as well. After the final rinsing in distilled water the membrane was dried in the open air for $10 \mathrm{~min}$ and scanned by the scanner (Samsung SCX-4x21).The images were analyzed by measuring the density of positively colored points with the help of the software for images treatment LI-COR Image Studio Lite Ver 5.2.

Quantitative determination of the general content of glycoproteins of the surface mucus in the rat colon and small intestine was conducted by the reaction with Folin reagent after mucus glycoproteins isolation by sulphosalicylic acid and their precipitation by phosphotungstic acid [18].

To determine the content of hexoses and fucose the mucus was hydrolyzed with $4 \mathrm{~N} \mathrm{HCl}(1: 1)$ during $1 \mathrm{~h}$ at $100{ }^{\circ} \mathrm{C}$. The content of hexoses was determined by the reaction with orcin reagent [19]. Fucose content was determined by the Dishe-Shettles method based on fucose reaction with hydrochloric cystein [20].

The content of hexosamines was determined by the reaction with acetylacetone in the base medium [21] after previous mucus hydrolysis with $8 \mathrm{~N} \mathrm{HCl}$ at $100{ }^{\circ} \mathrm{C}$ during $5 \mathrm{~h}$.
The content of sialic acids was determined by the Hess method [19] based on the interaction of sialic acids with aceto-hydrochloric reagent after previous mucus hydrolysis with $0.2 \mathrm{~N} \mathrm{H}_{2} \mathrm{SO}_{4}(1: 1)$ at $80^{\circ} \mathrm{C}$ during $1 \mathrm{~h}$.

The results concerning quantitative determination of the total content of glycoproteins in $1 \mathrm{mg}$, hexoses, fucose, hexosamines and sialic acids in $\mu \mathrm{mol}$ are presented in calculus per $1 \mathrm{ml}$ of mucus obtained as a result of its isolation by $6 \mathrm{~N} \mathrm{~N}$-acetyl1-cystein.

Statistical processing was conducted with the help of software Statistica 6.0. To estimate quantitative indices we determined the mean value (M), standard error of the mean (SEM). The normality hypothesis of distribution was checked for all available samples by the Shapiro-Wilk test. In cases when the normality hypothesis was denied, the probability in$\operatorname{dex}(P)$ was calculated on the basis of the rank nonparametric Mann-Whitney criterion. In other cases the calculation was made with the help of $t$-Student criterion. Critical level of probability of the statistical zero hypothesis $(P)$ was taken as 0.05 .

\section{Results and Discussion}

It is known that antibiotic therapy may result in the stable and long-term changes of gut microbiota $[4,5]$. Our previous studies [22] have shown that ceftriaxone administration during 14 days leads to disturbances in the qualitative and quantitative content of the parietal microbiota of the rat colon that are intensified in the course of time. Thus, no probable changes in the qualitative and quantitative content of the parietal microbiota were observed on the first day after ceftriaxone withdrawal. However 56 days after ceftriaxone treatment the number of lacto- and bifidobacteria in the content of the parietal microbiota decreased 1.3 and 1.8 times, respectively, $(P<0.05)$. Besides, conditionally pathogenic enterobacteria and those of Staphylococcus genus appeared among the parietal microbiota that is not typical of the given biotope.

Allowing for the fact that dysbiotic disturbances of the parietal microbiota are not revealed immediately but in due time after the antibiotic treatment, the change of carbohydrate composition of mucus was determined in different terms, in particular on the $15^{\text {th }}, 29^{\text {th }}$ and $72^{\text {nd }}$ days of the experiment.

Ceftriaxone administration during 14 days had no effect on the total content of glycoproteins of the surface mucus of the rat small intestine in all the 
terms of research (Fig. 1). No reliable changes were observed on the $15^{\text {th }}$ and $29^{\text {th }}$ days in the quantity of glycoproteins in the colon. But on the $72^{\text {nd }}$ day of the experiment this index decreased 1.3 times $(P<0.05)$ vs control group (Fig. $2, A)$. In contrast to the method of determining the total content of glycoproteins, which is based the Folin reagent binding to protein part of the molecule [18], the Schiff reaction (Fig. 2, B) has revealed a 1.9-fold decrease of the total content of glycans $(P<0.05$ in respect of indices in the control group) on the $72^{\text {nd }}$ day of the experiment. Thus, changes in the mucus barrier composition are connected not only with the decrease of the total number of glycoproteins, but also with deterioration of the glycan core. This confirms the outstanding role of the latter in protection of protein part of mucins.

The detected changes in content of the colon surface mucus glycoproteins coincide in time with shifts in the composition of parietal microbiota [22]. These data as well as the lack of changes in the content of glycoproteins of small intestine terminal part (Fig. 1), allow us to suppose a leading role of microbiota in maintaining the mucus barrier integrity. At the same time these changes evidence for the decrease of mucus barrier stability in remote terms after antibiotic therapy and can result in deterioration of bowels homeostasis. There are data of Wlodarska et al. [3] in favor of this supposition. It has been established that the uptake of metronidasole raises susceptibility of mice to $C$. rodentium-induced colitis due to the decrease of thickness of the inner mucus layer and, as a result, high pro-inflammatory bacterial stimulation of epithelium.
It is known that resistance of the bowel mucosa depends to a considerable extent not only on the content of glycoproteins but also on the composition and length of their side carbohydrate chains, protecting polypeptides from proteolysis, as well as limit penetration of macromolecules, including bacterial toxins, to epithelium cells [23]. So, it is expedient to estimate not only total quantity of surface mucus glycoproteins, but also qualitative composition of their carbohydrate residues, in particular, the content of hexoses, hexosamines, fucose and sialic acids.

Quantity of hexoses in the content of glycoproteins of the rat colon surface mucus did not reliably change immediately after ceftriaxone therapy. However, on the $72^{\text {nd }}$ day of the experiment one could observe a 1.2-fold decrease of hexoses content $(P<0.05)$ compared with the control values (Fig. 3). That corresponded to a decrease of the total quantity of glycoproteins obtained by the semiquantitative method with the help of Schiff-reaction.

A reliable decrease of fucose content, intensified in the course of time, was also observed. Thus, on the $29^{\text {th }}$ day of the experiment (14 days after ceftriaxone withdrawal) the content of fucose decrease 1.4 times, on the $72^{\text {nd }}$ day -3.1 times $(P<0.05)$ (Fig. 4). The results obtained confirm gradual appearance of qualitative changes of mucus glycoproteins in remote terms after ceftriaxone administration that may be accompanied by shortening of carbohydrate chains of glucoproteins.

Further we determined the content of hexosamines mainly localized in the core part of mucin glycans $[8,9]$. Investigation of the content of the rat colon surface mucus has shown no reliable chang-
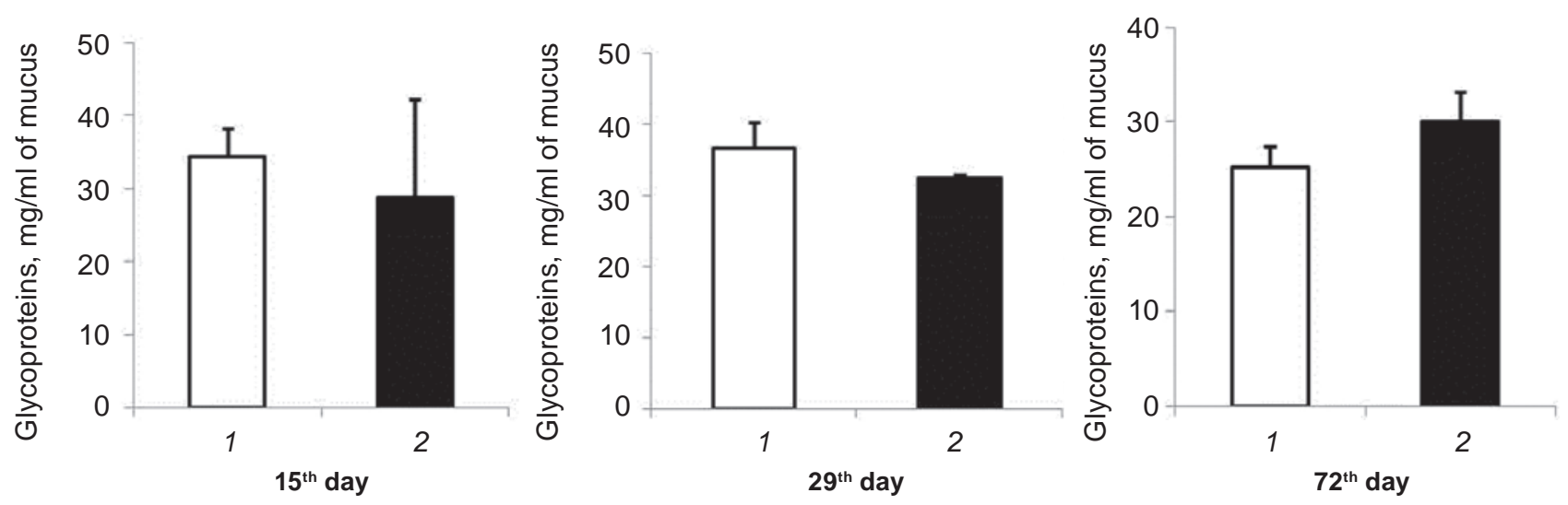

Fig. 1. Glycoprotein content in the surface mucus of the rat small intestine in different terms after ceftriaxone administration (300 mg/kg, i.m., 14 days): reaction with Folin reagent after isolatin by sulfosalicylic acid; $M \pm S E M ; n=24 ; 1$ - control, 2 - ceftriaxone 
$A$
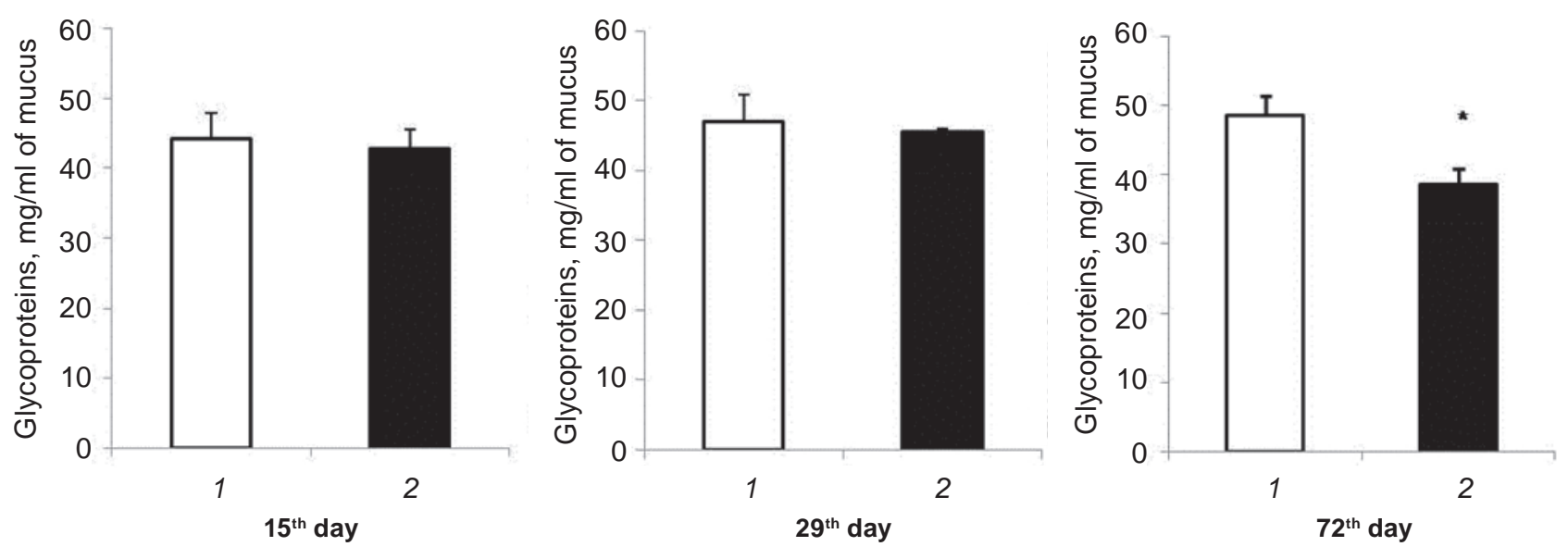

$B$
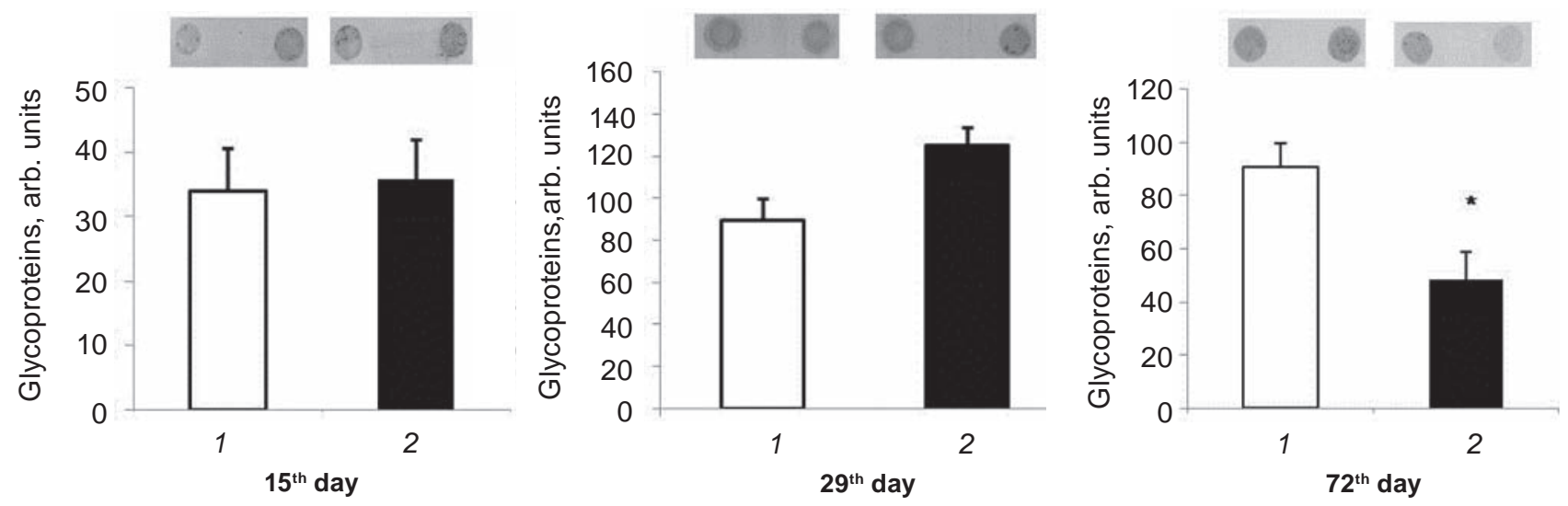

Fig. 2. Glycoprotein content in the rat colon surface mucus in different terms after ceftriaxone administration (300 mg/kg, i.m., 14 days): A - reaction with Folin reagent after isolation by sulfosalicylic acid; $B$ - Schiffreaction method on $P V D F-$-membrane; $M \pm S E M ; n=24 ; 1$-control, 2 - ceftriaxone; ${ }^{*} P<0.05$ relative to the control group indices
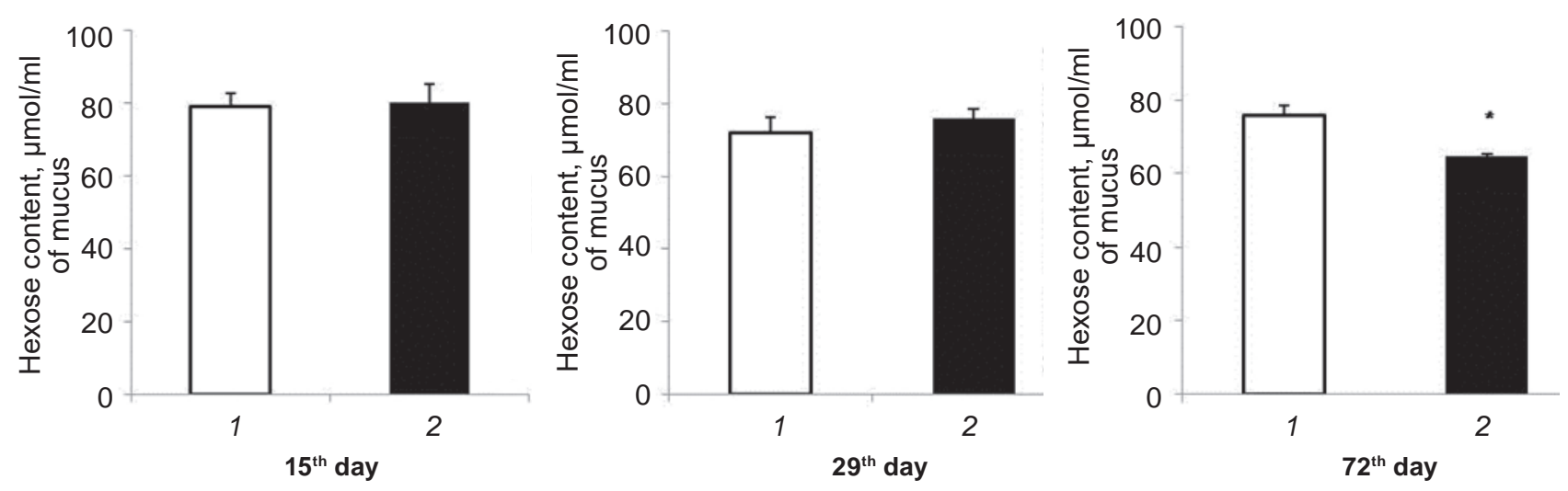

Fig. 3. Hexoses content in the rat colon surface mucus in different terms of ceftriaxone administration (300 $\mathrm{mg}$ ) $\mathrm{kg}$, i.m., 14 days); $M \pm S E M ; n=24 ; 1$ - control, 2 - ceftriaxone; $* P<0.05$ relative to the control group indices 

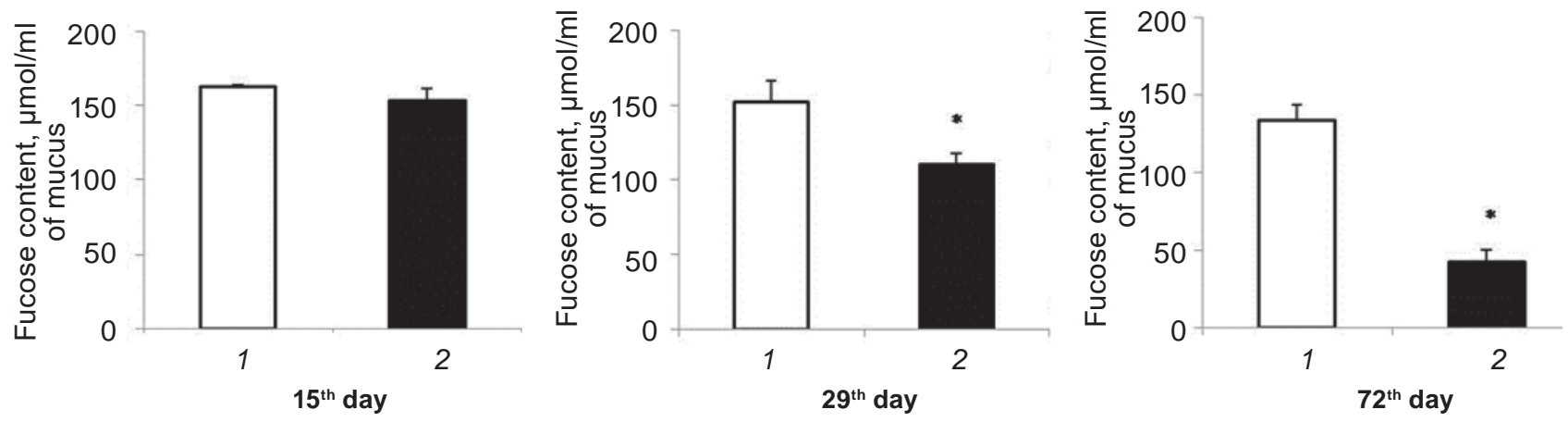

Fig. 4. Fucose content in the rat colon surface mucus in different terms after ceftriaxone administration (300 mg/kg i.m., 14 days); $M \pm S E M ; n=24 ; 1-$ control, 2 - ceftriaxone; $* P<0.05$ relative to the control group indices

es in hexosamine contents in different terms after ceftriaxone administration (Fig. 5). The absence of changes in the content of hexosamines, against the background of the decrease of glycoproteins content, may evidence for shortening the oligosaccharide part of molecules. It is shown [24] that treatment of glycoproteins of the normal mucus by a weak solution of the acid, which induces splitting-off residues of fucose and sialic acids, increases quantity of Thomsen-Friedenreich (TF) antigen - galactoso $\beta-1,3-\mathrm{N}$ acetylgalactosamine (Gal $\beta 1-3$ GalNAc $\alpha-$ ), which is a core carbohydrate structure of O-bound mucin oligosaccharides. Such changes were found in the mucus samples of patients with ulcerous colitis or bowel adenocarcinoma. So, the increase of TF antigen in mucins composition may be explained by the decrease of fucosylation of glycoproteins.

The described changes can result in disturbances of mucus viscosity and affect its interaction with microorganisms, electrolytes, protective proteins, and thus decrease the efficiency of the mucus layer functions.

Residues of sialic acids are distributed at the ends of oligosaccharide chains of glycoprotein molecules. In particular, as was noted, GalNAc sialation in C6 position terminates the elongation of glycan chain [8]. We marked the 1.5 -fold increase $(P<0.05)$ of the content of sialic acids (Fig. 6). The increase of mucins sialation is typical under inflammatory diseases of the bowel [14]. Thus the increase of the content of short O-bound antigens, such as sialyl Tn (sialyl- $\alpha 2,6 \mathrm{~N}$-acetylgalactosamine $\alpha$-bound to serine or threonine of the protein core) was revealed in the colon mucus composition of patients with ulcerous colitis [26].

The revealed changes in carbohydrate composition of the rat colon surface mucus in remote terms after ceasing ceftriaxone therapy may evidence for disturbances of post-translation modification of mucins. This leads to shortening the carbohydrate
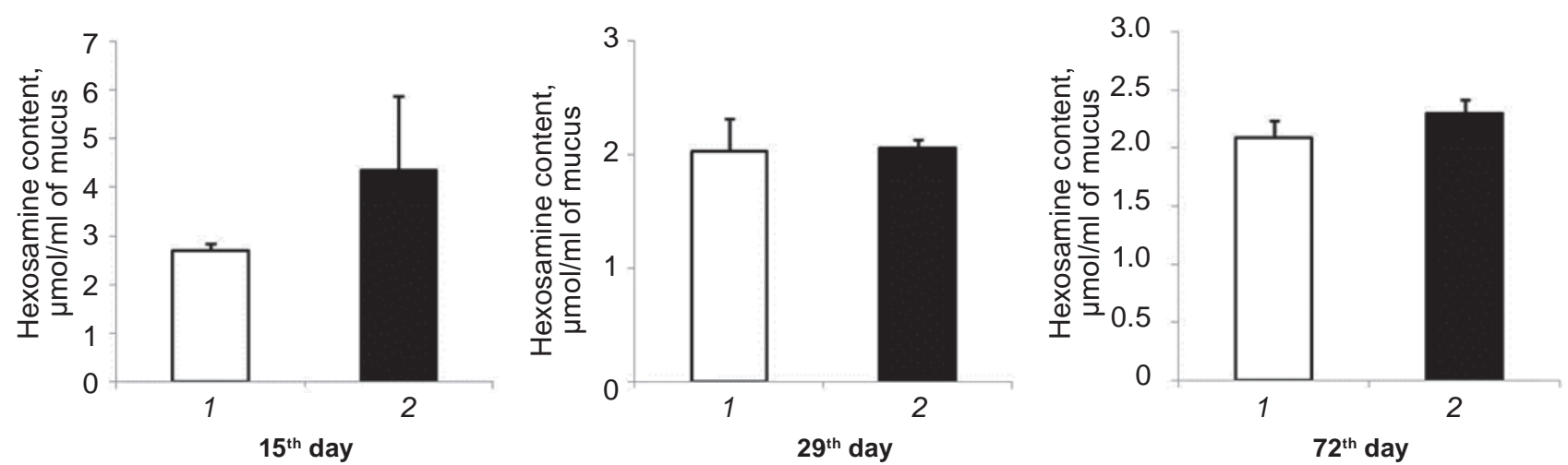

Fig. 5. Hexosamines content in the rat colon surface mucus in different terms after ceftriaxone administration (300 mg/kg i.m., 14 days); $M \pm S E M ; n=24$; control, 2 - ceftriaxone; $* P<0.05$ relative to the control group indices 

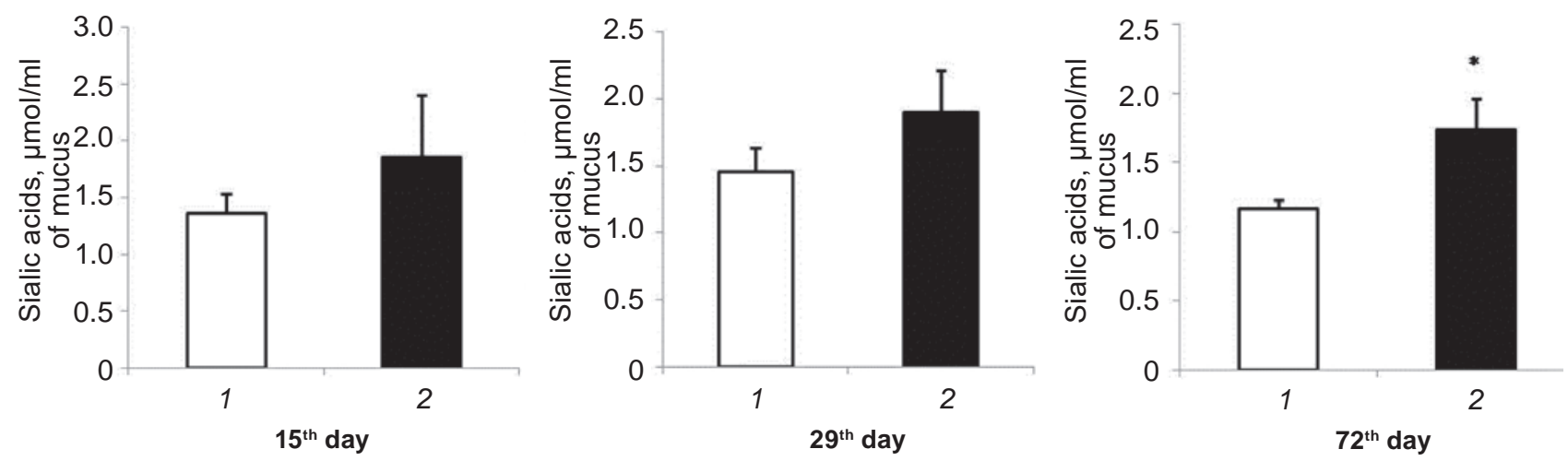

Fig. 6. Content of sialic acids in the rat colon surface mucus in different terms after ceftriaxone administration (300 mg/kg i.m., 14 days); $M \pm S E M ; n=24$; control, 2 - ceftriaxone; ${ }^{*} P<0.05$ relative to the control group indices

chains of glycoprotein molecule and their premature termination by residues of sialic acids. Since mucins glycosylation is a dynamic process and is moduled by the expression of specific glycosyltransferases, these changes may appear at the expense of increasing $\mathrm{pH}$ in Golgi apparatus mediated by inflammatory cytokins formed as a result of microbiota interaction with the bowel epithelium surface [27].

Thus, ceftriaxone administration during 14 days leads to the disturbance of the state of the surface mucus barrier of the rat colon in remote terms after the antibiotic therapy. The total quantity of glycoproteins of the rat colon surface mucus decreases on the $72^{\text {nd }}$ day of the experiment. That is accompanied by qualitative changes in the structure of glycan part of mucins, i.e., by a decrease of mucoses and fucose content, while the number of hexosmines does not change and the level of sialation of mucus glycoproteins increases. Such a character of changes in mucus composition is typical when IBD is developing [13, 14, 26]. The mucus barrier disturbance leads to dysregulation of interaction between epithelium cells, immune cells of the mucosa own plate and bowel microbiota. The excessive effect of microbe antigens is accompanied by release by epithelial cells of the inflammatory cytokins and chemokins, such as interleukin (IL) 1, IL6, IL8.

Polymorphonuclear neutrophils are first to respond to disturbances of the mucus barrier and to appearance of transepithelial gradient of microbial and cell chemoattractants. Activated neutrophils release a number of proteases having a potential effect on the functioning of the epithelial barrier by changing the structure and functions of epithelial cell-tocell contacts. As a result the dysfunction of the epi- thelial barrier can maintain pathologic inflammation of the mucus. However, the regulation disturbance of the bowel barrier function is not the only factor that contributes to IBD development. Thus, relatives of patients with Crohn's disease had the increased bowel epithelium permeability, which was not accompanied by inflammation development that confirms IBD polyetiology [28]. So, the results obtained confirm that antibiotic therapy can increase susceptibility to IBD development at the expense of the disturbance of the bowel mucus barrier functioning.

\section{ВУГЛЕВОДНИЙ СКЛАД ПОВЕРХНЕВОГО СЛИЗУ КИШЕЧНИКА ЩУРІВ ПІСЛЯ ВВЕДЕННЯ ЦЕФТРИАКСОНУ}

\author{
Ю. В. Голота, Я. А. Олефір, Т. В. Довбинчук, \\ Г. М. Толстанова
ННЦ «Інститут біології та медицини»,
Київський національний університет імені Тараса Шевченка, Україна; e-mail: gtolstanova@gmail.com

Епідеміологічні дослідження показали, що використання антибіотиків істотно підвищує ризик розвитку запальних захворювань кишечника. Одним із потенційних механізмів такої залежності $\epsilon$ порушення функціонування його слизового бар'єра. Метою дослідження було з'ясувати як змінюється вуглеводний склад та загальний вміст глікопротеїнів поверхневого слизу кишечника щурів після введення антибіотика цефтриаксону. Дослідження проводили на щурах-самцях лінії Вістар (140-160 г). Цефтриаксон (300 мг/кг, в/м) вводили щоденно впродовж 14 
днів. Загальний вміст глікопротеїнів слизу, гексо3, гексозамінів, фукози та сіалових кислот визначали на 15-, 29-ту та 72-гу добу експерименту в термінальному відділі тонкої та в товстій кишці. Введення цефтриаксону не впливало на загальний вміст глікопротеїнів поверхневого слизу тонкої кишки щурів. У товстій кишці на 72-гу добу спостерігалось вірогідне зниження в 1,3 раза $(P<0,05)$ вмісту глікопротеїнів у поверхневій слизі. Ці зміни супроводжувалися зниженням вмісту гексоз в 1,2 раза $(P<0,05)$ і фукози 3,1 раза $(P<0,05)$ та підвищенням в 1,5 раза $(P<0,05)$ рівня сіалових кислот. Отже, введення цефтриаксону індукує віддалені в часі зміни вмісту та вуглеводного складу глікопротеїнів слизу товстої кишки щурів, які відповідають таким за розвитку запальних захворювань кишечника.

К л ю ч о в с с лов а: антибіотики, глікопротеїни, гексози, фукоза, гексозаміни, сіалові кислоти.

\section{УГЛЕВОДНЫЙ СОСТАВ ПОВЕРХНОСТНОЙ СЛИЗИ КИШЕЧНИКА КРЫС ПОСЛЕ ВВЕДЕНИЯ ЦЕФТРИАКСОНА}

\author{
Ю. В. Голота, Я. А. Олефир, \\ T. В. Довбинчук, А. Н. Толстанова
УНЦ «Институт биологии и медицины», Киевский национальный университет имени Тараса Шевченко, Украина; e-mail: gtolstanova@gmail.com

Эпидемиологические исследования показали, что применение антибиотиков существенно повышает риск развития воспалительных заболеваний кишечника. Одним из потенциальных механизмов такой зависимости является нарушение функционирования его слизистого барьера. Целью исследования было выяснить как изменяется углеводный состав и общее содержание гликопротеинов поверхностной слизи кишечника крыс после введения антибиотика цефтриаксона. Исследования проводили на крысах-самцах линии Вистар (140-160 г). Цефтриаксон (300 мг/кг, в/м) вводили ежедневно в течение 14 дней. Общее содержание гликопротеинов слизи, гексоз, гексозаминов, фукозы и сиаловых кислот определяли на 15-, 29- и 72-е сутки эксперимента в терминальном отделе тощей кишки и в ободочной кишке. Введение цефтриаксона не влияло на общее содержание гликопротеинов поверхностной слизи тонкой кишки крыс. В толстой кишке на 72-е сутки наблюдалось достоверное снижение содержания гликопротеинов в 1,3 раза $(P<0,05)$. Эти изменения сопровождались уменьшением содержания в 1,2 раза $(P<0,05)$ гексоз и 3,1 раза $(P<0,05)$ фукозы и повышением в 1,5 раза $(P<0,05)$ уровня сиаловых кислот поверхностной слизи толстой кишки крыс. Следовательно, введение цефтриаксона индуцирует отдаленные во времени изменения в количестве и углеводном составе гликопротеинов слизи толстой кишки крыс, которые соответствуют таковым при развитии воспалительных заболеваний кишечника.

К люче вы е с ло в а: антибиотики, гликопротеины, гексозы, фукоза, гексозамины, сиаловые кислоты.

\section{References}

1. Shaw SY, Blanchard JF, Bernstein CN. Association between the use of antibiotics and new diagnoses of Crohn's disease and ulcerative colitis. Am J Gastroenterol. 2011; 106(12): 21332142.

2. Hviid A, Svanström H, Frisch M. Antibiotic use and inflammatory bowel diseases in childhood. Gut. 2011; 60(1): 49-54.

3. Wlodarska M, Willing B, Keeney KM, Menendez A, Bergstrom KS, Gill N, Russell SL, Vallance BA, Finlay BB. Antibiotic treatment alters the colonic mucus layer and predisposes the host to exacerbated Citrobacter rodentiuminduced colitis. Infect Immun. 2011; 79(4): 15361545.

4. Jernberg C, Löfmark S, Edlund C, Jansson JK. Long-term ecological impacts of antibiotic administration on the human intestinal microbiota. ISME J. 2007; 1(1): 56-66.

5. Antonopoulos DA, Huse SM, Morrison HG, Schmidt TM, Sogin ML, Young VB. Reproducible community dynamics of the gastrointestinal microbiota following antibiotic perturbation. Infect Immun. 2009; 77(6): 23672375 .

6. Johansson ME, Larsson JM, Hansson GC. The two mucus layers of colon are organized by the MUC2 mucin, whereas the outer layer is a legislator of host-microbial interactions. Proc 
Natl Acad Sci USA. 2011; 108(Suppl 1): 46594665.

7. McGuckin MA, Lindén SK, Sutton P, Florin TH. Mucin dynamics and enteric pathogens. Nat Rev Microbiol. 2011; 9(4): 265-278.

8. Larsson JM, Karlsson H, Sjövall H, Hansson GC. A complex, but uniform O-glycosylation of the human MUC2 mucin from colonic biopsies analyzed by nanoLC/MSn. Glycobiology. 2009; 19(7): 756-766.

9. Karlsson NG, Herrmann A, Karlsson $\mathrm{H}$, Johansson ME, Carlstedt I, Hansson GC. The glycosylation of rat intestinal Muc2 mucin varies between rat strains and the small and large intestine. A study of O-linked oligosaccharides by a mass spectrometric approach. $J$ Biol Chem. 1997; 272(43): 27025-27034.

10. An G, Wei B, Xia B, McDaniel JM, Ju T, Cummings RD, Braun J, Xia L. Increased susceptibility to colitis and colorectal tumors in mice lacking core 3-derived O-glycans. $J$ Exp Med. 2007; 204(6): 1417-1429.

11. Fu J, Wei B, Wen T, Johansson ME, Liu X, Bradford E, Thomsson KA, McGee S, Mansour L, Tong M, McDaniel JM, Sferra TJ, Turner JR, Chen H, Hansson GC, Braun J, Xia L. Loss of intestinal core 1-derived O-glycans causes spontaneous colitis in mice. $J$ Clin Invest. 2011; 121(4): 1657-1666.

12. Corfield AP, Wagner SA, Clamp JR, Kriaris MS, Hoskins LC. Mucin degradation in the human colon: production of sialidase, sialate $\mathrm{O}$-acetylesterase, N-acetylneuraminate lyase, arylesterase, and glycosulfatase activities by strains of fecal bacteria. Infect Immun. 1992; 60(10): 3971-3978.

13. Shirazi T, Longman RJ, Corfield AP, Probert CS. Mucins and inflammatory bowel disease. Postgrad Med J. 2000; 76(898): 473-478.

14. Sun J, Shen X, Li Y, Guo Z, Zhu W, Zuo L, Zhao J, Gu L, Gong J, Li J. Therapeutic Potential to Modify the Mucus Barrier in Inflammatory Bowel Disease. Nutrients. 2016; 8(1). pii: E44.

15. Carlstedt-Duke B, Høverstad T, Lingaas E, Norin KE, Saxerholt H, Steinbakk M, Midtvedt T. Influence of antibiotics on intestinal mucin in healthy subjects. Eur J Clin Microbiol. 1986; 5(6): 634-638.
16. Sidorenko SV, Ushkalova EA. Clinical and pharmacoeconomic effectiveness of ceftriaxone in surgical patients. Pharmateca. 2003; 64(1): 11.

17. Akiba Y, Guth PH, Engel E, Nastaskin I, Kaunitz JD. Dynamic regulation of mucus gel thickness in rat duodenum. Am $J$ Physiol Gastrointest Liver Physiol. 2000; 279(2): G437-G447.

18. Romanenko EG, Klenyna IA. Method for determining of total glycoproteins in saliva. World Med. Biol. 2012; 4: 91-93. (In Russian).

19. Kolb VH, Kamyshnikov VS. Clinical Biochemistry. Minsk: Belarus, 1976. 380 p. (In Russian).

20. Dishe Z, Shettles LB. A specific color reaction of methylpentoses and a spectrophotometric micromethod for their determination. $\mathrm{J}$ Biol Chem. 1948; 175(2): 595-603.

21. Romanenko EG, Klenyna IA. Method for determination of hexosamines in saliva. Bul Probl Biol Med. 2013; 2(1): 215-217. (In Russian).

22. Holota Y, Dzyubenko N, Ostapchuk A, Dovbynchuk T, Serhiychuk T, Putnikov A, Kaji I, Tolstanova G. Long-Term Effect of Antibiotic Therapy on Colonic Levels of Shortchain Fatty Acids (SCFA), FFA2 and FFA3 Receptors. The $15^{\text {th }}$ Int. Conf. of Ulcer Research. Ottawa, Canada, 2015. P. 48.

23. McGuckin MA, Eri R, Simms LA, Florin TH, Radford-Smith G. Intestinal barrier dysfunction in inflammatory bowel diseases. Inflamm Bowel Dis. 2009; 15(1): 100-113.

24. Campbell BJ, Finnie IA, Hounsell EF, Rhodes JM. Direct demonstration of increased expression of Thomsen-Friedenreich (TF) antigen in colonic adenocarcinoma and ulcerative colitis mucin and its concealment in normal mucin. J Clin Invest. 1995; 95(2): 571-576.

25. Okada Y, Sotozono M, Sakai N, Yonei T, Nakanishi S, Tsuji T. Fucosylated ThomsenFriedenreich antigen in alpha-anomeric configuration in human gastric surface epithelia: an allogeneic carbohydrate antigen possibly controlled by the Se gene. $J$ Histochem Cytochem. 1994; 42(3): 371-376.

26. Karlén P, Young E, Broström O, Löfberg R, Tribukait B, Ost K, Bodian C, Itzkowitz S. Sialyl-Tn antigen as a marker of colon cancer 
risk in ulcerative colitis: relation to dysplasia and DNA aneuploidy. Gastroenterology. 1998; 115(6): 1395-1404.

27. Campbell BJ, Yu LG, Rhodes JM. Altered glycosylation in inflammatory bowel disease: a possible role in cancer development. Glycoconj J. 2001; 18(11-12): 851-858.
28. Luissint AC, Parkos CA, Nusrat A. Inflammation and the Intestinal Barrier: Leukocyte-Epithelial Cell Interactions, Cell Junction Remodeling, and Mucosal Repair. Gastroenterology. 2016; 151(4): 616-632.

Received 28.09.2016 